\title{
A Probe into Chinese Learners' Negative Cultural Transfer in EFL
}

\author{
Honglin Zhu \\ School of Foreign Languages, Changzhou University, Changzhou, China \\ Email: zhl57921@yahoo.com.cn
}

\begin{abstract}
Modern linguistics considers culture learning as one of the most important processes in learning a foreign language. The present article explores a list of the negative cultural transfers caused by Chinese EFL learners owing to the cultural differences between Chinese and Western culture, with a focus on the negative transfer manifested on surface and deep structure.
\end{abstract}

Index Terms-EFL learning, cultural difference, cultural transfer, negative transfer

\section{INTRODUCTION}

The study of negative cultural transfer can be traced back to the 1950s. Whorf (1956) and other linguists conducted many studies of the relationships between culture and language. They held that culture and language are inseparably interwoven, and that sociocultural values and beliefs determine the way people think and speak. In Linguistics across Cultures, Robert Lado (1957) made his point clear that native cultural transfer was one of the main barriers to second language learning. Later, more researchers carried out the further study on negative cultural transfer For example, by examining the significance of understanding the sociocultural values of the target language for those engaged in both second language learning and intercultural communication, Damen (1987) and Kramsch (1993) found that the mastery of second language patterns alone does not ensure effective communication in the target language, and cultural education is absolutely essential for both second language acquisition and effective intercultural communication. By employing speech act theory, Beebe (1988) and Wolfson(1989)further examined the ways second language learners typically attempt to use speech patterns from their native language to accomplish speech acts in the second language.

\section{Types OF Negative CUltural Transfer}

Generally speaking, the study of the negative transfer can be specified as the study in the scope of surface-structure transfer and deep-structure transfer. The surface structure transfer, according to Beebe (1988), refers to the practice "socialcultural transfer" and this type of transfer can be easily observed. The deep structure is integrated into our thinking at such a basic level that we take it for granted. Joseph Shaules (2010) holds that deep culture infuences our thinking and values in ways that we generally aren't aware of. We rely on it in everyday life to interact, communicate, and interpret what people do. Therefore, a further study on both the surface and deep structure of negative cultural transfer is of great importance to Chinese EFL learners.

\section{Negative Cultural Transfer On SuRface Structure}

The following aspects are listed to illustrate the influence of negative transfer committed by Chinese learners on the surface structure.

\section{A. The Influence of Negative Transfer on Pragmatic Forms}

Practice in EFL teaching and learning revealed problems and addressed needs in carrying out the study on the negative pragmatic transfer. Here are some examples:

1. No smoking please.

This sign can be found in many public sites in China. Grammatically speaking, there is nothing wrong with it. However, if analyzed from the pragmatic angle, this sentence is inappropriate in at least two ways. First, the use of "please" often depends on the relationship between the interlocutors and the intention of the speech act. If it is uttered by a superior, the word "please" is often not desired; if it is spoken by a subordinate to his superior, the word "please' is often compulsory. Second, it also depends on whether we want to conduct a request or a suggestion. However, many Chinese learners overlooked the use of "please" in English and over-generalized the use of this word due to the fact that in Chinese the word 'please' is used without any distinction as it does in English (Liu, 2000). Liu (1991) and Chen (1992) also found the following sentence in their students' composition:

2. Our English teacher has peaches and plums everywhere in China.

In this sentence, the English words "peach" and "plum" both refer to fruits. However, Chinese learners use them to mean "students". This is a typical negative transfer from Chinese to English, because English vocabulary "peach" and 
"plum" do not contain such connotative meaning.

Transfers like this can be found frequently by Chinese learners whether in written or spoken form and our explanations are often inadequate if we take these sentences simply as errors or pragmatic failures.

\section{B. The Influence of Negative Transfer on Translation}

In EFL learning, quite a number of Chinese learners like to find Chinese equivalents for their English counterparts, which is likely to entail a negative transfer. For example, someone translates “注意身体”(take care of yourself) as “notice your body"; translate “日光浴”(sunbathe) as "shine the sun". These translations made by the speaker leave the native speaker of English unable to understand appropriately.

There are other similar cases that many English words are translated into Chinese literally. However, owing to the different cultural background, people may have a subconscious standard and values of their culture to guide conduct and thought. Take the word "favorite son" as an example. Most Chinese learners would translate it as “宠儿”. However, the translation is inaccurate, because the word “宠儿” is a derogatory term in Chinese. In English, “宠儿” should be translated as "favorite". "Favorite son" is a commendatory title given to George Washington by American people for the reason that George Washington led American people to the victory of the War of Independence. In order to express the respect and love for him, American people call him "favorite son".

\section{The Influence of Negative Transfer on Connotative Meanings}

Language is the carrier of culture, so the same word or expression set in different cultural contexts might have different connotation. "Peacock", "yellow", and "seagull" with their respective English connotative meaning of "vanity", "cowardliness", and disaster" are, in Chinese, symbols of "auspiciousness", "obscenity", and "braveness" correspondingly. Other words or expressions like "blue room", "swan song", and "let the cat out of the bag" make no sense at all if translated literally into Chinese. Still others like "Pandora's box", "the apple of the eye", and "baker's dozen" fall into another category that draws heavily on the reader's knowledge of the Bible, Greek and Roman myths, western literary works and history.

The connotative meaning is the emotional reaction of vocabulary in people's minds, and it varies in different cultural background and customs. Take the color word "red" as an example. The Chinese people like red and they often associate red with the sun and the color of fire. As the sun and fire bring people brightness, warmth and happiness, "red" then implies joyousness, auspiciousness, happiness and animation, and so on. In western culture, however, because of the traditional culture "bullfight", people always treat "red" as "red for danger". So in English, "red" is used to express fire, blood, violence, etc. For instance, "red ruin" refers to “火灾” and "red battle" in Chinese is “血战”.

Like color words, animal words also tend to be negatively transferred. In China, tiger is regarded as the king of the forest. People appreciate tiger because they think it is the most mighty and powerful animal. On the contrary, this laurel should be given to lion in western culture, which symbolizes a person who is brave and full of valor, and who enjoys a high position. "The British Lion" refers to England and "a literary lion" is the expression of a famous person in literature.

\section{The Influence of Negative Transfer on Speech Act}

As one of the most important components in pragmatics, speech act theory serves as a key to the phenomenon of cultural transfer. According to Austin (1962), on any occasion, the action of producing an utterance involves three related acts: a locutionary act, an illocutionary act and a perlocutionary act. An analysis of the illocutionary force of an utterance can help people understand its cultural meaning. For example, in a Chinese context, "Where are you going?" often functions as greeting. In a Western context, however, it may be mistaken for an intrusion of privacy. Later, J. Searle $(1969,1979)$ revised and developed the theory of speech act and further divided the speech act into direct and indirect speech act. In a direct speech act, there is a direct relationship between form and function, when an imperative is used to perform a request (for example, "close the door!"), while in an indirect speech act, the illocutionary force of the act is not derivable from the surface structure as when an interrogative form serves as a request (for example, "Could you close the door?"). Without doubt, indirect speech acts tend to show greater politeness in English than direct speech acts. Searle (1979) also holds that in indirect speech acts, the speaker tries to convey more implicit meanings by means of the shared verbal or non-verbal background information between the him and the hearer, as well as the reasonable inference of the hearer. However, if the speaker and the hearer of the conversation come from different cultures, communicative failures are likely to occur. For example, Chinese EFL learners often use such imperative structures as "Teacher, explain it to me (in the classroom)!", "Let me look at that watch (in the shop)!" which may be considered as impolite in western social communication.

\section{Negative Cultural Transfer on DeEP Structure}

Living in or visiting other countries often brings us into contact with people who have different deep-culture settings. Deep culture, according to Hampden-Turner \& Trompenaars (2000), refers to "the unconscious meanings, values, norms and hidden assumptions that allow us to interpret our experiences as we interact with other people. These shared meanings form a framework that acts as a starting point for our sense of what it means to be human, what constitutes 
normal behavior, how to make moral/ethical choices, and what we see generally as reasonable". Dai Weidong and Zhang Honglin (2000) hold that negative transfer of deep culture is not easily perceived because of the existence of social culture and value systems at the psychological layer. However, it is these cultural values that have an impact on people's thoughts and behaviors and are liable to cause misunderstanding or ineffective communication.

\section{A. Negative Transfer on Thought Patterns}

Different cultures give birth to different thought patterns. Based on the logic system of Greece, western thought patterns are quite different from those of Chinese. The western line of argument is generally deductive, with a topic introduced at the beginning and followed by the minor or supporting arguments. This pattern contrasts with the Chinese inductive pattern, in which minor points of the argument are placed first and then the main point is presented.

Another point is that westerners tend to be "analytic" (beginning with the separate parts and piecing them together to make a whole) as opposed to the Chinese "global" tendency (beginning with the picture) (Nelson, 1995).Besides, in western culture, being straightforward is regarded as an acceptable manner in communication, while in Chinese culture, being implicit is more appreciated, and the following dialogue is an example.

Mr. Jones: It looks like we're going to have to keep the production line running on Saturday.

Mr. Wu: I see.

Mr. Jones: Can you come in on Saturday?

Mr. Wu: Yes. I think so.

Mr. Jones: That'll be a great help.

Mr. Wu: Yes. Saturday's a special day, did you know?

Mr. Jones: How do you mean?

Mr. Wu: It's my son's birthday.

Mr. Jones: How nice. I hope you all enjoy it very much.

Mr. Wu: Thank you. I appreciate your understanding (Storti, 1994).

The dialogue between an American employer and a Chinese employee indicates that although Mr. Wu is good at English, due to the negative transfer of thought patterns, he experienced a failure in cross-cultural communication. His real intention was that he wanted to give the hint that he didn't want to work an extra shift on Saturday, because in Chinese culture, direct refusal is considered impolite, so he chose to refuse implicitly by saying "I see." However, the boss didn't understand him and further forced him to land in a desperate situation. In order to save the boss's face, he had to answer "Yes, I think so", which, in Chinese context just meant "I hear what you say, but I am reluctant to come".

\section{B. Negative Transfer in Value Systems}

The value system is one of the key factors that shape the behavior of the members of a culture. These value systems are influenced by a variety of factors and it has the characteristic of being unique, enduring, and relatively stable. Due to the striking contrast in these value systems, negative cultural transfer is very likely to occur.

For example, western people resent the invasion of their privacy by other people and this can be embodied by the proverb such as "an Englishman's home is his castle". The basic reason is that they respect privacy, would try every means to protect privacy; while the concept of "privacy" is rarely perceived by Chinese EFL learners because what is regarded as "privacy" in the west is not necessarily thought of as such in Chinese cultural setting. Therefore, it is not unusual for Chinese to inquire about an individual's age, salary, marriage status, etc. to show their concern, friendship and intimacy even when they meet for the first time.

Another contrast can be reflected in their view about collectivism and individualism. China is a nation deeply marked by collectivism which lays greater emphasis on the views, needs and goals of the in-group (relatives, clans, and organizations) rather than oneself (Triandis 1990). A famous saying from Confucius that "if one wants to establish himself, he should help others to establish themselves at first" best shows the Chinese collective thought. Although a derogatory term in Chinese, individualism is highly valued in the west, especially by American people, who put high premium on success through personal efforts. Many English proverbs that reflect the respect for individualism are embraced by Americans, for instance, "every man is the architect of his own fortune", or "pull yourself up by your own boot straps".

Different value orientations can also be noticed in their views about friendship. In Chinese culture, such proverbs as "At home you count on your parents, outside on your friends" and "All men are brothers within the world" indicate how important friendship is. With this orientation in mind, Chinese people are often irritated at the American "transient friendship" In fact, it is social mobility and the desire for change that make Americans devalue long-term friendship.

\section{Negative Transfer in Ethical System}

In a broad sense, Ethics refers to judgments that focus on "degrees of rightness and wrongness, virtue and vice, and obligation in human behavior" (Johannesen 1996). Ethics is an elusive topic. But as far as intercultural interaction is concerned, we find that there is no universally acceptable moral code. In other words, most ethical norms are products of specific cultures. Therefore, it is not surprising that the ethical norms appropriate in one culture may be inappropriate in another. For example, as a tradition, Chinese people value the virtue of respecting the old, including showing filial 
obedience to parents, senior relatives, and addressing the old with respect. Chinese often address the elderly "Old Wang", "Old Grandpa" etc. in daily life, in which "old" represents "respectable". This addressing, however, is rarely adopted by western people because in western culture, "old" may mean "useless" and "out of date".

\section{CONCLUSION}

After discussing some typical negative transfers in EFL, we may find that culture has a great influence on people's concept and behavior in communication and EFL learning involves developing learners' understanding of their own language and culture in relation to target language and culture. In fact, it is a dialogue allowing for reaching a common ground for negotiation, where various differences are recognized, mediated, and accepted.

On the other hand, both EFL teachers and learners are expected to pay attention not only to the negative transfer but also to the fact that the cultural difference may raise great barriers to EFL. Especially for Chinese learners of English, they need to develop sensitivity to explicit and implicit western culture and their impact on communication, and to acquire the skills of discovering and interpreting cultures, values, beliefs and even behaviors which lie beneath the surface of western culture. It is no easy task for English learners to acquire empathy with the people and culture of second language, and it is hard to avoid thoroughly pragmatic errors in EFL learning. However, an awareness of such differences will certainly help learners better understand the different cultural connotation, pave the way for a better understanding and finally help learners achieve communicative objectives.

\section{REFERENCES}

[1] Austin, J.L. (1962). How to Do Things with Words. Oxford: Clarendon Press.

[2] Beebe, L. M. (1988). Issues in Second Language Acquisition: Multiple Perceptives. New York: Newbury House.

[3] Chen, Jiangping (1992).The Chinese Students' Mother Tongue Transfer Phenomenon in English Learning. Changsha: Hunan Education Press

[4] Dai, Weidong \& Zhang, Honglin (2000). The Negative Cultural Transfer in Foreign Language Communication and Its Implication for English Teaching Reforms. Foreign Language World. 2

[5] Damen, L. (1987) Culture Learning: The Fifth Dimension in the Language Classroom. Reading, MA: Addison Wesley.

[6] Hampden-Turner, C., \& Trompenaars, F. (2000). Building Cross-Cultural Competence: How to Create Wealth from Conflicting Values. New Haven \& London: Yale University Press.

[7] Johannesen, R.K. (1996). Ethics in Human Communication. $4^{\text {th }}$ ed. Prospect Heights, IL: Waveland Press.

[8] Joseph, S. (2010). A Beginner's Guide to the Deep Culture Experience: Beneath the Surface. London: Intercultural Press.

[9] Kramsch, C. (1993). Context and Culture in Language Teaching. Oxford: Oxford University Press.

[10] Lado, R. (1957). Linguistics across Cultures: Applied Linguistics for Language Teachers. Ann Arbor: University of Michigan Press.

[11] Liu, Dilin. (1995). Sociocultural Transfer and Its Effect on Second Language Speakers' Communication. International Journal of Intercultural Relations. vol.19

[12] Liu, Shaozhong. (2000). A Comparative Study of "please" between Chinese and English: An Example of Negative Pragmatic Transfer. Journal of Foreign Languages. vol.5

[13] Searle, J. (1969). Speech Acts. An Essay in the Philosophy of Language. Cambridge: Cambridge University Press.

[14] Searle, J. (1979). Expression and Meaning: Studies in the Theory of Speech Acts. Cambridge: Cambridge University Press.

[15] Storti, C. (1994). Cross-Cultural Dialogues. Yarmouth: International Press.

[16] Triandis, H. C. (1990). Cross-Cultural Studies of Individualism and Collectivism. In J. J. Berman, (ed). Cross-Cultural Perspectives. Lincoln: University of Nebraska Press.

[17] Whorf, B.L. (1956). Language Thought \& Reality. Cambridge, MA: MIT Press.

[18] Wolfson, N. (1989). Sociolinguistics. New York: Newbury House Publishers.

Honglin Zhu was born in Nanjing, China in 1957. He received his B.A in English from Hangzhou University, China in 1982.

$\mathrm{He}$ is currently an associate professor in the School of Foreign Languages, Changzhou University, Changzhou, China. His research interests include second language acquisition and college English teaching. 